\title{
Pelatihan Media BIG MAZE Bagi Guru-Guru Aisyah Pendukung Selama Daring Alfitriani Siregar ${ }^{{ }^{*}}$; Nadlrah Naimi ${ }^{2}$ \\ ${ }^{1 *}$ Universiats Muhammadiyah Sumatera Utara

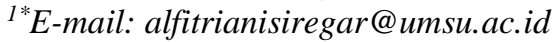

\begin{abstract}
Abstrak
Pengabdian masyarakat ini bertujuan untuk memberikan pelatihan mengajar melalui media permainan edukatif BIG MAZE bagi guru-guru Aisiyah selama daring. Permainan edukatif, yaitu Maze, adalah sebuah sistem jalur yang rumit, berliku-liku, serta memiliki banyak jalan buntu. Pada saat dirumah, anak dengan mudah belajar melalui media BIG MAZE, adalah B (Bergerak) adalah stimulus pada gerak badan, tangan dan kaki anak. I (Ingat) adalah melatih sensor ingatan anak, melalui Bahasa, angka, huruf. G(guna) adalah melakukan kegiatan dari hasil latihan yang dilakukan dalam Gerakan sebelumnya melalui sensor ingatan, dan akan mempengaruhi perkembangan kognitif anak. Kegiatan ini dilakukan dengan bekerjasama antara mitra Pimpinan Wilayah Aisyiyah Pendidikan Dasar dan Menengah Sumatera Utara dan guru-guru Aisyiyah Butstanul Athfal di Kota Medan. Metode yang diajarkan pada anak kepada 10 guru-guru dari ABA di Kota Medan dan telah dilakukan evaluasi, Kegiatan ini melalui 4 tahap, yakni (1) Persiapan, (2) Tindakan, (3) Observasi, dan (4) Evaluasi. Hasil yang dilakukan anak-anak sangat antusias dalam menggunakan alat permainan edukatif BIG MAZE di rumah secara dalam jaringan (daring).
\end{abstract}

Kata kunci: BIG MAZE, Media, Permainan, Daring

\section{Abstract}

This community service is aimed to provide teaching training through BIG MAZE educational game media for Aisiyah' teachers during online. The educational game, Maze, is complicated, tortuous, and deadlocked track system. At home, children easily learn through the media BIG MAZE, is B (Bergerak) for move is a stimulus to the child's body movements, hands and feet. I (Ingat) for remember is to train the child's memory sensors, through language, numbers, letters. G(Guna) for use is to do the activities of the results of exercises done in the previous movement through memory sensors, and will affect the cognitive development of children. This activity was carried out in collaboration between Aisyiyah Regional Leadership of Primary and Secondary Educational in North Sumatera and Aisyiyah Butstanul Athfal' teachers in Medan partners. The method is taught for children of 10 teachers from ABA in Medan and has been evaluated, this activity through 4 stages: (1) preparation, (2) action, (3) observation, and (4) evaluation. The results of the children were very enthusiastic using by BIG MAZE of educational games tool at home online.

Keywords: BIG MAZE, Media, Games, Online

\section{Pendahuluan}

Sejak wabah Covid-19 menyerang dunia dengan data penyebaran yang mengkwatirkan, termasuk Indonesia, dan sampai bulan Juli belum juga ditemukan obat antivirus SARS-CoV-2. Salah satu pengabdian yang dilakukan merupakan daerah zona merah di kota Medan, agar pengabdian ini berlangsung dengan aman tanpa ada yang terinfeksi virus, seyogyannya dapat dilakukan dalam jaringan (daring). Ada banyak pelajaran yang bisa diambil dari pandemi covid 19, mulai dari pendidikan, pekerjaan, keluarga dan anak. Pendidikan yang biasanya berlangsung tatap muka di kelas, sejak pandemi maka kelas dilakukan secara daring. Pekerjaan guru dan orangtua biasa dilakukan diluar rumah, sejak pandemi maka mereka melakukan di dalam rumah. Keluarga yang selalunya tidak sempat berbicara bersama pada saat hari kerja, maka setiap hari ayah, ibu dan anak-anak dapat bekerja, belajar, bermain bersama-sama tanpa ada batas. Menurut Sudarsana
(2020) menjelaskan pembelajaran dilakukan secara daring harus membutuhkan kreatifitas dan inovasi dari para pendidik sehingga dalam mentransfer pengetahuan dan ketrampilan dapat berjalan dengan baik. Dalam pembelajaran secara daring yang diajarkan kepada anak usia dini membutuhkan banyak kreativitas dari para guru, sehingga materi yang diajarkan dapat tercapai kepada anak, namun tidak pula tujuan pembelajaran harus keseluruhannya tercapai karena anak usia dini membutuhkan pembentukan ajaran agama atau pendidikan islam dan pendalaman karakter pada saat di rumah bersama orang tua.

Pendidikan Islam mengajarakan tentang mengenal adanya Tuhan dan berakhlak baik. Untuk berakhlak baik harus diajar sejak umur usia dini, agar anak terdidik dalam ajaran islam dan memahami pendidikan islam kelak mereka dewasa. Menurut Siregar (2018) Penanaman dasar-dasar Akidah dapat dilakukan kepada anak sejak mereka dapat berdiri dengan tegak. Akhlak 
merupakan fondasi utama untuk membentuk kepribadian manusia. Karena akhlak merupakan salah satu kunci jatuh bangunnya peradaban suatu bangsa, serta anak usia dini adalah sang peradaban masa depan kita dimasa akan datang.

Masyarakat Aisyiyah bersama-sama mewujudkan Pendidikan usia dini dengan mendirikan Taman Kanakkanak Aisyiyah Bustanul Athfal (TK ABA) di setiap daerah. Tempat Pendidikan anak usia dini diselenggarakan merupakan; membentuk anak berkualitas, bahwa anak yang tumbuh dan berkembang sesuai dengan tingkat perkembangannya sehingga memiliki kesiapan yang optimal di dalam memasuki Pendidikan Dasar serta mengarungi kehidupan di masa dewasa (Siregar, 2018). Pendidikan di TK ABA juga memberikan perkembangan dalam pembelajaran sesuai tingkat usia anak. Didalam Pendidikan anak usia dini perlu adanya permainan indoor atau out door.

Pada bulan lalu Aisyiyah mengadakan acara jalan Bersama dengan anak-anak TK Aisyiah se-Sumatera Utara, ibunda PWA Dikdasmen Sumatera Utara yaitu Bunda Rusni,S.Pd mengatakan "Masyarakat Aisyiyah bersama membimbing anak-anak dengan Pendidikan akhlakul karimah sejak dini”. Beliau menyarankan untuk memerhatikan anak-anak di usia 3-6 tahun mudah mendapatkan prilaku-prilaku yang positif atau negative di usia golden age nya, sehingga harus diajarkan akhlakul karimah didalam prilaku anak. Untuk memberikan Pendidikan islam dengan akhlakul karimah tidak mudah hanya dengan cerita, mereka membutuhkan Pendidikan yang menyenangkan di saat usia dini dengan cara bermain. Bermain untuk anak usia dini merupakan suatu kegiatan yang dilakukan dengan atau tanpa alat, yang menghasilkan makna dan memberikan informasi bertujuan memberikan kesenangan dan mengembangkan imajinasi anak. Menurut Triharso (2013) Pendidikan usia dini menyatakan bahwa imajinasi anak merupakan dunia anak. Maka setiap benda yang dimainkan berfungsi sesuai dengan imajinasi anak. Misalnya dengan penggaris dipegang dengan beranggapan bahwa itu adalah pesawat. Ada permainan edukatif yaitu Maze yang dapat melatih anak dalam berimajinasi.

Permasalahan yang dihadapi oleh guru-guru TK ABA di kota Medan merupakan pengajaran $\mathrm{Al}$ islam tentang akhlakul karimah. Mereka selalu mengajarkan melalui cerita yang monoton sehingga anak-anak mampu mendengar hanya hitungan detik kemudian anak-anak kembali ribut dikelas. Guru-guru TK ABA di kota Medan mulai meningkatkan kreatifitas mengajar mereka melalui gerakan-gerakan badan, suara dan intonasi tinggi rendah sesuai peran dalam cerita, atau menggunakan atribut gaya sesuai peran yang ada didalam cerita. Namun belum mampu membuat anak diam untuk mendengarkan cerita dari guru, sehingga dalam hitungan menit anak-anak kembali ribut dan mengganggu teman lainnya yang mendengarkan cerita dari guru. Mitra PWA Didaksmen di Divisi TK/PAUD bekerjasama dengan UMSU untuk meningkatkan kualitas belajar anak-anak di kelas. Dan memberikan pembelajaran karakter yang islami kepada anak-anak dengan mengajar $\mathrm{Al}$ islam tentang akhlakul karimah dengan cara bermain permainan edukatif menggunakan BIG MAZE.

Labirin dalam Bahasa Inggris Maze adalah sebuah sistem jalur yang rumit, berliku-liku, serta memiliki banyak jalan buntu. Dr. Maria Montessori mengembangkan "Metode Montessori" sebagai hasil dari penelitiannya terhadap perkembangan intelektual anak. Beberapa alat permainan edukatif ciptaan Montessori, yaitu: alat timbangan, silinder dengan ukuran serial sepuluh ukuran, tongkat-tongkat desimeter dan meter, gambar-gambar untuk dicontoh untuk mengembangkan motorik halus, bujur telur, maze dan lain-lain. Pramudito (2017) pun mengatakan alat permainan edukatif Maze Bangun Datar yang layak untuk mata pelajaran Matematika mampu menjadi media pembelajan dengan baik.

Membuat permainan edukatif dengan penanaman dasar-dasar aqidah dan keimanan perlu adanya pembelajaran yang mengajarkan kepada anak-anak sesuai perkembangan anak. Menurut Susanto (Siregar, 2018) perlu diperhatikan pada fungsi-fungsi memberikan layanan sesuai perkembangan anak;

a) Pengembangan Potensi; kegiatan anak bukan hanya untuk mencapai pada kepentingan pertumbuhan dan perkembangan, dari usia dini dapat memberikan perkembangan melalui bakat-bakat yang dimiliki anak.

b) Penanaman Dasar-dasar Akidah dan Keimanan; pendidikan ibadah dapat diberikan ketika anak sudah mampu berdiri tegak dengan kakinya, dan mampu mengontrol dirinya agar tetap tenang.

c) Pembentukan dan pembiasaan perilaku-perilaku yang diharapkan; Anak merupakan the golden age di usia dini. Artinya masa mereka merupakan fase yang sangat fundamental bagi perkembangan individu karena pada fase ini terjadi pembentukan dan pengembangan pribadi anak.

d) Pengembangan motivasi dan sikap belajar yang positif; kegiatan pendidikan anak perlu adanya motivasi belajar dari orang dewasa untuk menstimulasi anak agar melatih sikap belajar yang baik.

e) Pemilihan Permainan; bermain merupakan awal dari perkembangan kreativitas karena dengan kegiatan bermain anak dapat mengungkapkan gagasan atau ide secara bebas.

Dari lima diatas merupakan saling hubung antara pengembangan potensi, penanaman aqidah, dengan pembentukan prilaku, terhadap motivasi dan sikap belajar positia anak melalui pemilihan permainan yang edukatif dengan menggunakan BIG MAZE. 
Dari analisis situasi diatas sebagai masyarakat yang tidak produktif secara ekonomi dari kedua mitra maka akan disimpulkan rumusan permasalahan sebagai diskusi antara mitra dan ketua.

\section{Bahan dan Metode}

Berdasarkan permasalahaan yang dihadapi oleh mitra, maka sebagai gambaran rancangan awal dan tahap akhir, sebagai berikut:

a. Pelatihan mengajarkan $\mathrm{Al}$ islam tentang akhlakul karimah sesuai anak usia dini

b. Memberikan pengajaran alat permainan edukatif secara simulasi

c. Melatih guru-guru mengajar kepada anak-anak dalam penanaman akhlak terpuji melalui BIG MAZE

Pelaksanaan kegiatan pengabdian ini mengikuti aktivitas pelaksanaan penelitian tindakan yang terdiri dari persiapan, pelaksanaan (tindakan), observasi, dan valuasi

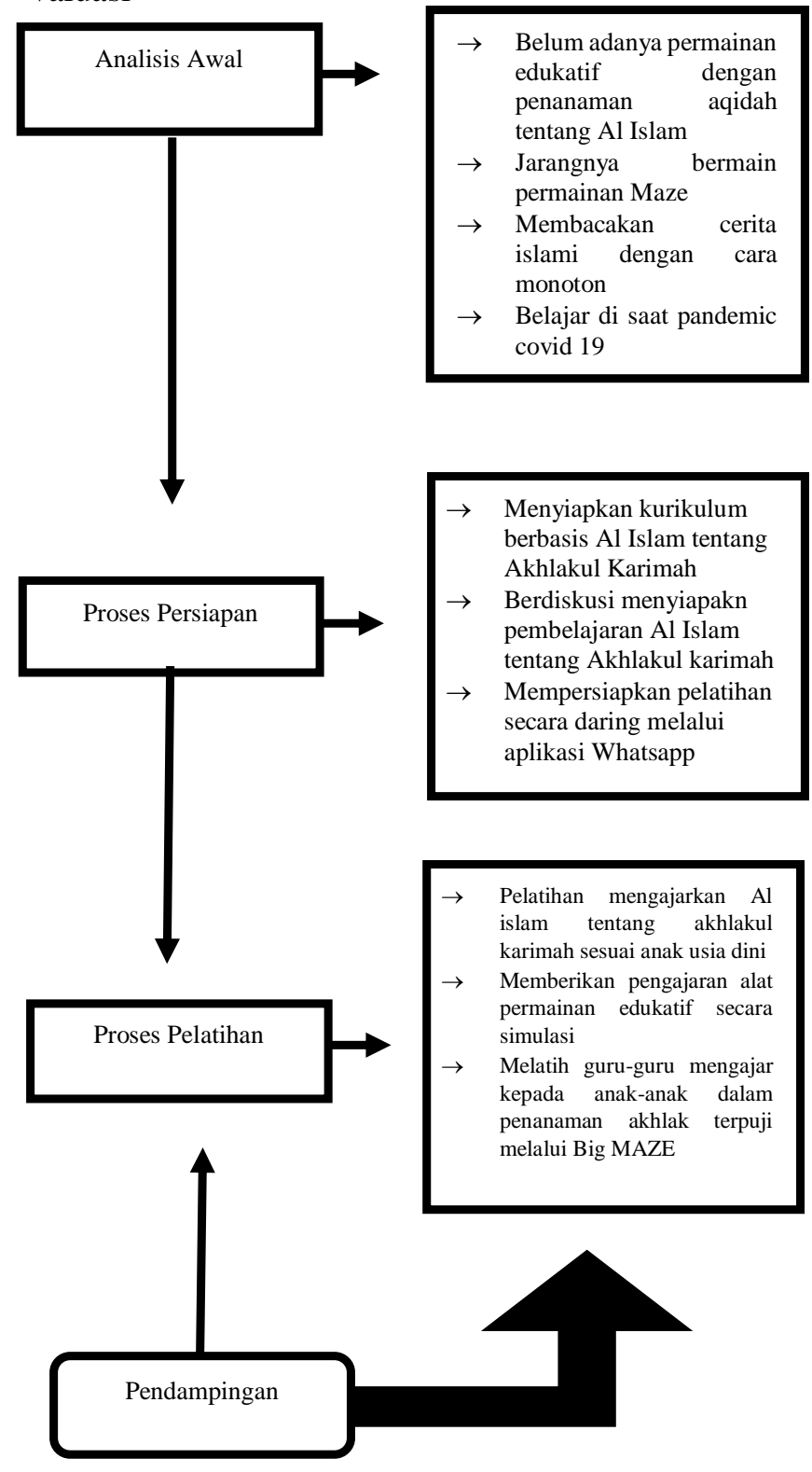

Gambar 1. Alur Kegiatan
Kegiatan ini dilakukan secara daring melalui zoom cloud meeting, kedua mitra diantranya mitra PWA Didasmen Sumut dan 10 orang guru-guru ABA kota Medan, diantaranya;

Tabel 1.

Nama-nama Guru ABA

\begin{tabular}{lll}
\hline No & Nama & Sekolah \\
\hline 1 & Helvinawati,S.Pd & ABA 41 \\
2 & Tripawati Ranor, S.Pd & ABA 05 \\
3 & Lely Suarti S.Pd AUD & ABA 16 \\
4 & Adelafita, S.Pd & ABA 36 \\
5 & Susi Ratnawati,S.Pd & ABA 01 \\
6 & Ayu Lestari,S.Pd & ABA MELATI 09081 \\
7 & Aida Fitriana, S.Pd & ABA 18 \\
8 & Nuraida Fitry Lubis, S.Pd AUD & ABA 14 \\
9 & Siti Saleha, S.Ag.,S.Pd & ABA 06 \\
10 & Yuwenika, S.Pd & ABA 04 \\
\hline
\end{tabular}

Bahan yang digunakan dalam pelatihan, diantaranya;

1) Kertas

2) Spidol

3) Lakban

Cara membuatnya:

1) Buatlah gambar tangan dan kaki anak di atas kertas dengan menggunakan spidol

2) Atur jarak tangan dan kaki untuk permainan

3) Gunakan lakban untuk merekatkertas agar tidak terbang atau robek

4) Buatla jalur jalan maze, lalu atur letak "mulai" dan "selesai" jalur jalan maze.

\section{Hasil dan Pembahasan}

\section{Persiapan melakukan pertemuan daring}

Persiapan awal dalam pertemuan yang dilakukan pada 3 Desember 2019 dengan kedua mitra diantaranya Ibu Dra.Rusni sebagai Ketua PWA Didasmen Sumatera utara dan Ibu Yuwenika mewakili salah satu Guru TK ABA di Kota Medan bersepakat untuk melakukan kerjasama dalam pelatihan di Tempat TK ABA 04. Namun, Pada saat pandemi Covid 19 akhir maret 2020 dan sampai bulan juli daerah kota Medan, Sumatera Utara masih dalam zona merah, sehingga mengharuskan seluruh masyarakat melakukan kegiatan dirumah, tidak dibenarkan untuk berjumpa tatap muka, maka kegiatan dilakukan secara daring.

Kegiatan diubah dengan melakukan diskusi dan pelatihan secara daring. Saya dan guru-guru berdiskusi melalui diskusi kelompok secara daring melalui aplikasi Whatsapp.

Tim pelaksana mengisntruksikan ada beberapa peraturan pada saat zoom berlangsung, diantaranya:

1) Peserta menggunakan nama asli sesuai form pendaftaran saat join zoom.

2) Peserta mematikan audio (mute) pada saat pembicara bicara, jika ingin bicara akan diberi ijin oleh moderator. 
3) Peserta tidak dibenarkan menggunakan layer gambar atau foto, diwajibkan membuka video ketika sedang berlangsung acara.

4) Peserta mengisi form kemajuan untuk tindakan setelah zoom berlangsung.

5) Peserta dapat bertanya setelah zoom berlangsung melalui Whatsapp Group.

Ada beberapa sesi pertanyaan dan pemateri oleh tim pelaksana dapat menjawab pada sesinya. Moderator oleh mahasiswa yaitu Glory semester IV FKIP Pendidikan Bahasa Inggris dan Indah semester II FAI Pendidikan Anak Usia Dini.

Persiapan kegiatan secara daring berlangsung pada tanggal 2 Juni 2020 dengan pemateri dari tim pelaksana. Tim melakukan pelatihan melalui aplikasi zoom cloud meeting.

\section{Pelaksanaan Zoom secara daring}

Kegiatan selanjutnya dilakukan secara daring melalui zoom cloud meeting menggunakan laptop atau telepon pintar. Kegiatan ini berlangsung dengan instruksi yang telah disampaikan pada persiapan awal. Tim mempersiapkan dengan menginstruksikan sebelum hari acara berlangsung dengan melakukan diskusi melalui Whatsapp Group.

Tim pengabdian juga memberikan pesan dengan mengirim id dan password pada zoom meeting yang dilakukan secara daring. Laman zoom meeting seperti https://us02web.zoom.us/j/962431761 ?pwd=RHRkeG

N2cGZ2UIJmdzl2eElLZ2R0Zz09 atau dapat memasukkan id zoom dan kode password yang berlangsung seperti Meeting ID: 9624351761 Password: Pendidikan.

Setelah semua guru masuk ke zoom meeting besarma moderator dan tim pelaksana, maka acara dimulai dengan pemateri pelatihan membuat media BIG MAZE, seperti gambar di bawah

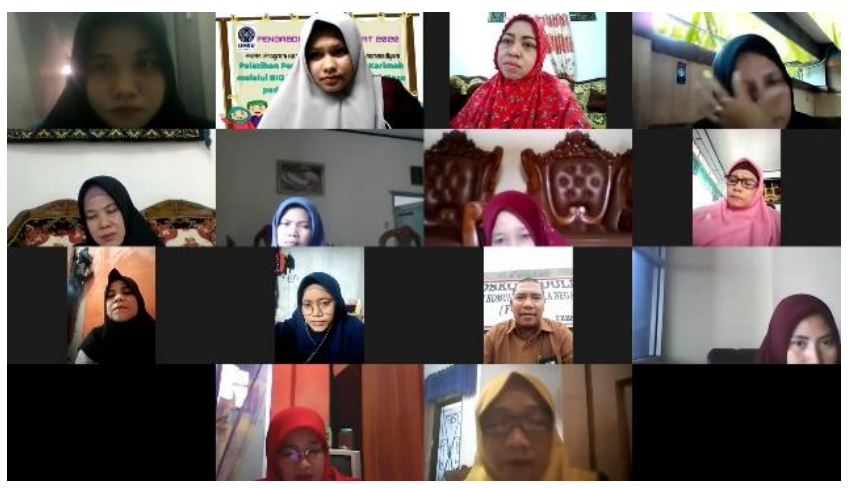

Gambar 2. Zoom cloud meeting

Pelatihan ini dilakukan dengan melatih guru-guru TK ABA di Kota Medan dengan menggunakan media BIG MAZE untuk mendukung pembelajaran daring selama dirumah. Pelatihan ini melatih guru-guru untuk mengajarkan ayah, ibu atau pendamping anak selama dirumah sebagai pengganti peran guru. Ayah, Ibu dan pendamping anak dapat mengajarkan anak-anak dengan mudah tanpa harus melakukan instruksi atau protokoler kesehatan.

Pelatihan media BIG MAZE bagi guru-guru merupakan tujuan dari beberapa perkembangan. BIG MAZE adalah B (Bergerak) adalah stimulus pada perkembangan gerak badan, tangan dan kaki anak (Syafaruddin, 2011). I (Ingat) adalah melatih sensor ingatan anak, melalui Bahasa, angka, huruf. Dan G (guna) adalah melakukan kegiatan dari hasil latihan yang dilakukan dalam gerakan sebelumnya melalui sensor ingatan, dan akan mempengaruhi perkembangan kognitif anak. Menurut Siregar (2018) ada beberapa karakteristik anak agar tumbuh kembang dengan pembelajaran dan bermain:

(1) Relatif tidak terstruktur, belajar dengan kebutuhan anak dengan bermain yang terarah. Mereka membutuhkan permainan yang menyenangkan tetapi diarahkan oleh ayah, ibu atau pendamping. Sehingga dengan BIG MAZE dapat bermain dengan melatih beberapa perkembangan anak.

(2) Pengalaman langsung, Sesuai dengan tingkat perkembangan berfikir dan cara belajar anak yang lazimnya masih terbatas pada cara berfikir kongkrit. Anak dapat bermain dengan BIG MAZE tanpa harus belajar mengingat, karena BIG MAZE dapat bermain sambal melatih kognitif anak.

(3) Suasana bermain dan menyenangkan (joy of learning), Permainan BIG MAZE adalah alat media pembelajaran yang edukatif, produk ini dapat melatih gerak badan anak, kaki, dan tangan anak. Sehingga anak dapat belajar dan juga bergerak dengan menyenangkan.

Produk BIG MAZE merupakan media pembelajaran menyenangkan, edukatif, dan melatih perkembangan motorik, Bahasa, kognitif, dan agama. Media BIG MAZE yang digunakan seperti gambar di bawah ini.

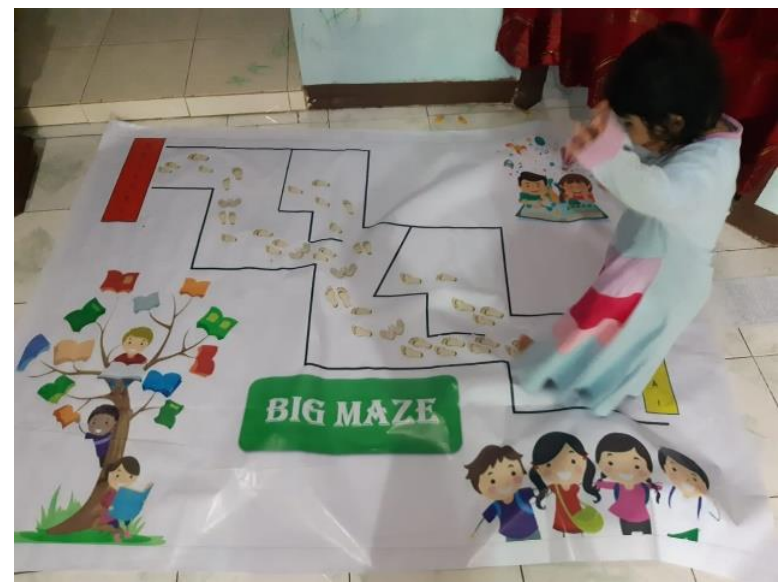

Gambar 3. Produk BIG MAZE

Produk yang melatih perkembangan anak dan motorik anak merupakan produk yang menyenangkan. 
Sebelum adanya produk ini, tim pengabdian melatih guru-guru dengan alat seadanya.

$$
\text { Cara belajar menggunakan BIG MAZE }
$$
diantaranya:

1) Tentukan Tema pembelajaran contohnya "Akhlak"

2) Berikan ingatan kepada anak dalam materi pembelajaran tentang "Akhlak"

3) Berikan latihan kembali agar anak ingat soal yang akan diberikan dengan menggunakan media pembelajaran BIG MAZE, contoh " Tangan mana yang kita gunakan pada saat bersalaman?" jawabannya adalah "tangan kanan"

4) Setelah mendapatkan materi pembelajaran, mulailah anak pada posisi jalur maze "mulai", dan beri pertanyaan dalam ingatan anak " Tangan mana yang kita gunakan pada saat bersalaman?"

5) Mulailah anak melangkah bergerak mengikuti tapak tangan dan jejak kaki dengan benar

6) Setelah sampai jalur jalan "selesai" tanyakan jawaban pada anak, maka jawabannya "tangan kanan"

7) Terapkan kepada anak untuk bersalaman langsung menggunakan tangan kanan anak.

8) Beri pertanyaan berulang dengan pertanyaan yang berbeda.

Setelah melakukan daring melalui zoom, tim akan melakukan observasi dengan berbagai pertanyaan dari para guru-guru.

\section{Observasi pendampingan kepada mitra}

Guru-guru dapat bertanya langsung melalui Whatsapp Group yang. Ada beberapa pertanyaan dari seorang guru dari ibu Siti, "apakah materi yang diajarkan harus materi akhlak?”. Pertanyaan ini menjadi pijakan oleh tim pelaksana, karena bukan hanya satu materi, guru-guru dapat menyampaikan materi tentang tumbuh-tumbuhan, hewan, transportasi, mengenalkan kosa kata Bahasa Inggris.

Pertanyaan yang menyinggung selama daring dari salah satu guru dari ibu Lely "Bagaimana cara untuk memotivasi orangtua agar mau ikutserta dalam pembelajaran daring?". Penggunaan internet memang menguras biaya apa lagi menggunakan zoom 1giga data internet bisa Rp 20.000,-, Namun ada sisi positifnya bahwa anak perlu belajar selama ada pendamping, maka peran guru digantikan oleh orangtua selama dirumah. Anak usia dini tidak harus belajar monoton, seperti menggambar, menulis, membaca buku cerita, namun anak harus dilatih motorik kasar seperti gerak tangan, gerak kaki dan badan. Selama dirumah anak usia dini tidak diharuskan belajar dengan giat namun terarah dan memperdalam nilai-nilai karakter dan ajaran agama dengan menggunakan BIG MAZE.

Observasi dari pertanyaan-pertanyaan guru dikembangkan dengan evaluasi, bagi guru tidak hanya mendengar pelatihan secara daring namun tim Volume 2, Nomor 2, 2020

ISSN 2657-1439 (Print), ISSN 2684-7043 (Online) pelaksana mengambil 4 guru sebagai bahan evaluasi yang dapat diterapkan di rumah secara daring.

\section{Evaluasi learn from home}

Learn from home artinya belajar dari rumah, anak bukan hanya belajar monoton, tetapi menanamkan nilinilai karakter, seperti:

1) Membantu ibu yang mencuci sayur, dapat mengenalkan anak nama-nama sayur, warna sayur, bentuk sayur dan rasa sayur.

2) Menolong ayah mengambilkan alat kerja, dapat mengenalkan anak palu, paku, obeng dan lain-lain.

3) Menemani kakak atau abang belajar daring, anak semangkin faham kegunaan laptop dan handphone, dapat mengenalkan anak alat-alat teknologi.

4) Memberi makan hewan peliharaan, mengenalkan anak dengan hewan dari fungsi telinga, kaki, dan makanan hewan.

5) Menyiram tanaman bersama ayah atau ibu, mengenalkan anak kebesaran Allah bahwa tumbuhtumbuhan ciptaan Allah

6) Memberi ojek online pengantar makanan, minuman dan barang dengan tip lebih.

Observasi dengan menggunakan media BIG MAZE menggunakan alat yang ada di rumah.

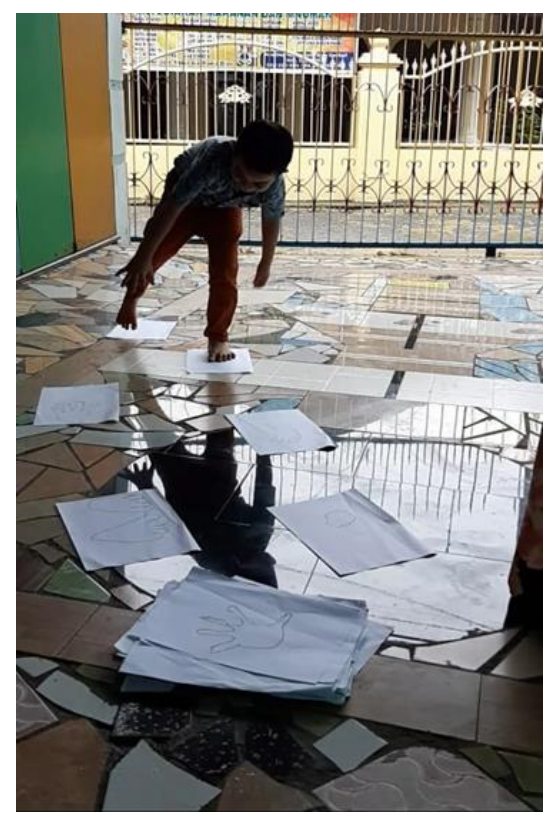

Gambar 4. Evaluasi secara daring

Kegiatan pada gambar 4. merupakan permainan dari media BIG MAZE selama masa pelatihan dan observasi di rumah. Anak-anak melakukan dengan bahan seadanya sehingga tim pelaksana dapat menilai tindakan, observasi dan evaluasi yang telah dilakukan dengan menggunakan media BIG MAZE. Ini adalah seorang anak bernama Al fiqri bersama pendamping, dia belajar rukun islam. Sebelum melakukan kegiatan, dia harus membuat gambar diatas kertas dengan menciplak tangan dan kakinya sendiri atas perintah 
pendamping. Kemudian pendampingnya merintahkan untuk membentuk jalur, agar dia dapat bergerak diatas kertas dengan gambar, seperti gambar kaki maka pijak kaki, gambar tangan tempel tangan diatas kertas. Pertanyaan materi rukun islam ada lima, silahkan nyanyikan. Kemudian anak mulai bergerak, setelah selesai mulai menjawab pertanyaan dengan menyanyi rukun islam.

\section{Kesimpulan dan Saran}

Kegiatan ini dilakukan bagi guru-guru TK ABA di kota medan secar daring, tim pelaksana memberikan pelatihan mengajar secara daring dengan menggunakan media BIG MAZE. Kegiatan ini dilakukan daring secara keseluran melalui zoom, lalu evaluasi guru melakukan daring dengan anak. Mereka melakukan instruksi dari guru, kemudian dilakukan kegiatan dengan ayah, ibu atau pendamping dirumah. Media BIG MAZE merupakan media yang melatih anak dalam perkembangan Bahasa, motorik, dan kognitif.

Bagi guru menerima dengan positif, karena anak tidak jenuh, bosan, dan aktif dapat bergerak. Guru juga dapat merubah materi yang akan diajarkan untuk anak, materi tumbuh-tumbuhan, hewan, transportasi dan materi yang lain. Media BIG MAZE ini adalah salah satu cara untuk pembelajaran daring untuk anak usia dini dengan bermain bersama pendamping.

\section{Ucapan Terima Kasih}

Tim pelaksana PKPM (Program Kemitraan Pengembangan Muhammadiyah) mengucapkan terima kasih kepada LPPM Universitas Muhammadiyah Sumatera Utara yang telah memberi dukungan atas pelaksanaan pengabdian masyarakat. Terima kasih kepada kedua mitra PWA Didasmen SUMUT dan Guru-guru ABA di Kota Medan atas dukungan dan izin dalam menyelenggarakan pengabdiam masyarakat.

\section{Daftar Rujukan}

Pramudito. (2017). Pengembangan Alat Permainan Edukatif Maze Bangun Datar Mata Pelajaran Matematika Kelas II SD. EJurnal Prodi Teknologi Pendidikan, VI (1)

Siregar, Alfitriani. (2018). Metode Pengajaran Bahasa Inggris Anak Usia Dini. Lembaga Penelitian Dan Penulisan Ilmiah Aqli: Medan ISBN: 978-602-53067-0-9

(2017). Pelatihan Tutor Paud

Dalam Pembuatan Media Buku Flannel Berbahasa Inggris. Jurnal Prodikmas. 2(1),115

(2018). Pengajaran Anak Usia Dini Melalui Buku Flanel Terintegrasi Dalam Bahasa Inggris. Paramasastra. 5(1), 104-123

Sudarsana, I Ketut dkk. (2020). Covid-19 Perspektif Pendidikan. Yayasan Kita Menulis
Syafaruddin dkk. (2011). Pendidikan Pra sekolah: Perspektif Islam \& Umum. Perdana Publishing: Medan. ISBN: 9786028935159

Triharso, Agung. (2013). Permainan Kreatif \& Edukatif untuk Anak Usia Dini. Andi Offset: Yogyakarta ISBN 9789792933864

Wahyudi, Dedi. (2017). Pengantar Akidah Akhlak dan Pembelajarannya. Lintang rasi aksara books: Yogyakarta. ISBN 9786027802483 